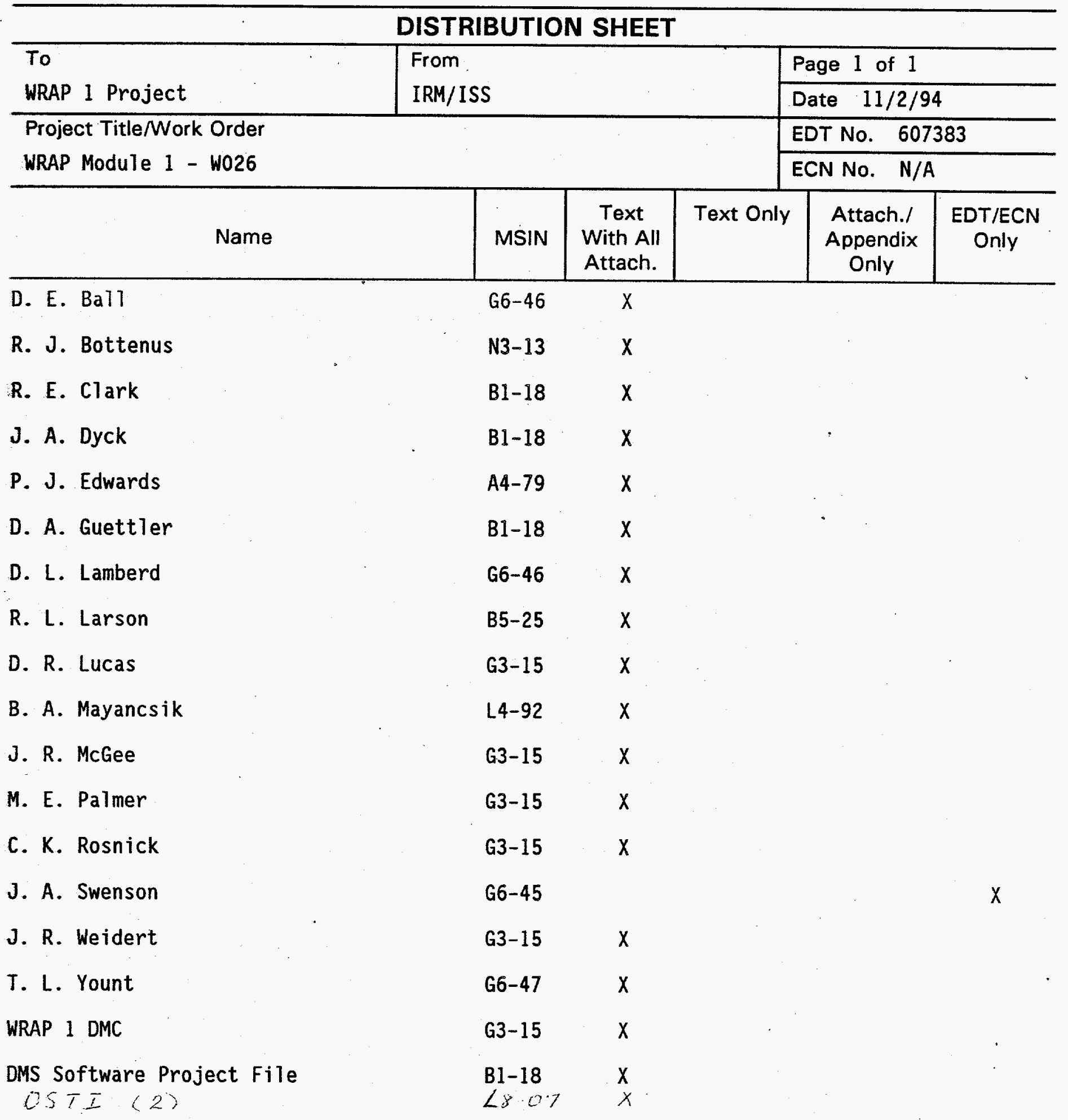




\section{DISCLAIMER}

Portions of this document may be illegible in electronic image products. Images are produced from the best available original document. 


\begin{tabular}{|l|l|r|}
\hline $\begin{array}{l}\text { 2. To: (Receiving Organization) } \\
\text { WRAP 1 Project }\end{array}$ & $\begin{array}{l}\text { 3. From: COriginating Organization) } \\
\text { BCSR/ISS }\end{array}$ & $\begin{array}{r}\text { 4. Related EDT No.: } \\
607376\end{array}$ \\
\hline $\begin{array}{l}\text { 5. Proj./Prog./Dept./Div.: } \\
\text { WRAP Module 1 - W026 }\end{array}$ & $\begin{array}{l}\text { 6. Cog. Engr.: } \\
\text { C. K. Rosnick }\end{array}$ & 7. Purchase Order No.: \\
N/A
\end{tabular}

8. Originator Remarks:

The WRAP 1 Data Management System Software Project.

Management PIan, WHC-SD-W026-SDP-001, REV 0 is distributed for approval.

11. Receiver Remarks:

9. Equip./Component No.:

$N / A$

10. System/Bldg./Facility: WRAP Module 1

12. Major Assm. Dwg. No.:

$N / A$

13. Permit/Permit Application No.: $N / A$

14. Required Response Date:

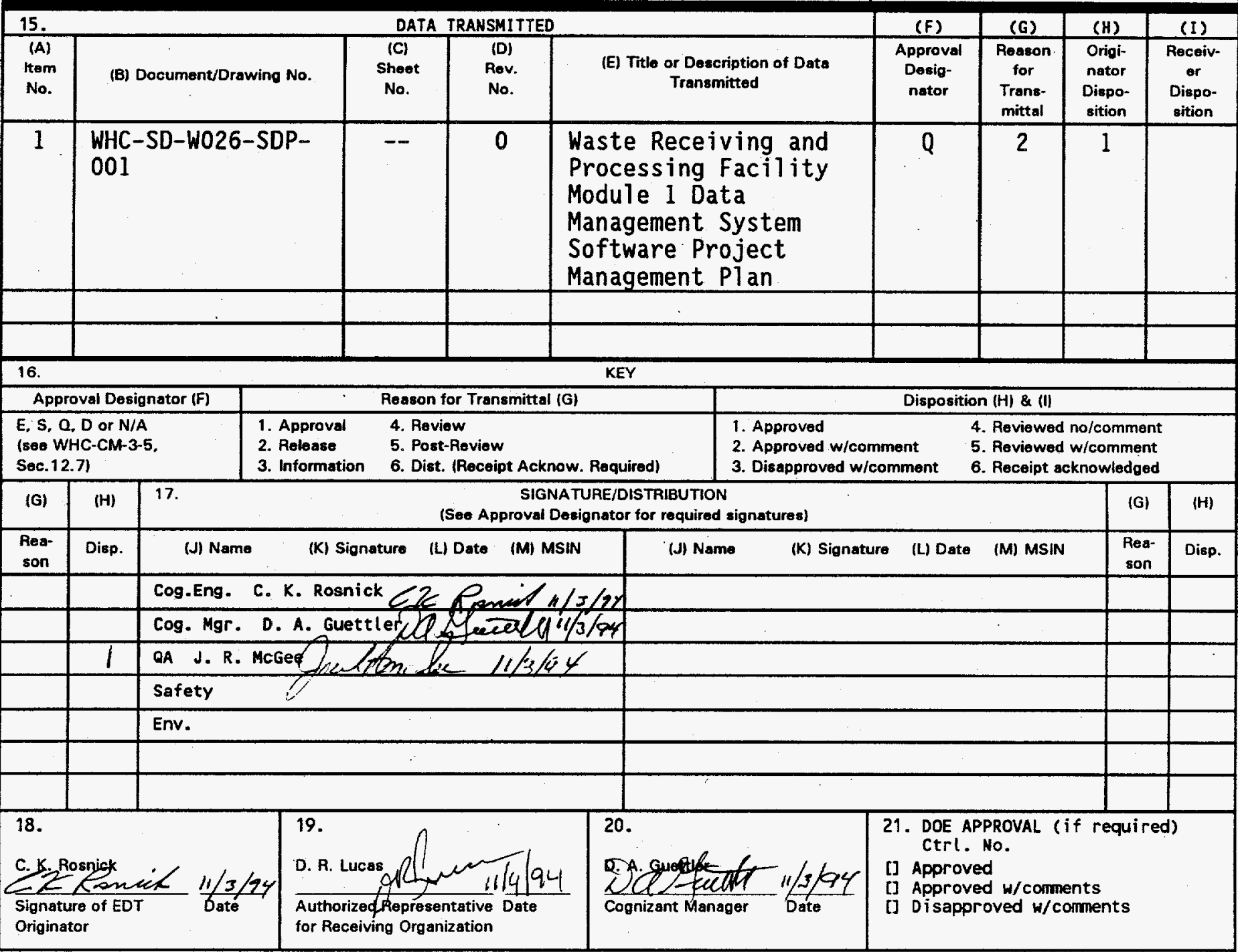




\section{RELEASE AUTHORIZATION}

Document Number: WHC-SD-W026-SDP-001, Rev. 0

Document Title: Data Management System Software Project Management Plan

Release Date: $\quad 11 / 10 / 94$

This document was reviewed following the procedures described in WHC-CM-3-4 and is:

APPROVED FOR PUBLIC RELEASE

WHC Information Release Administration Specialist:

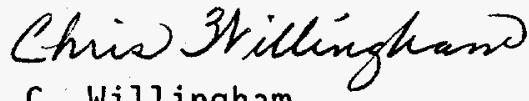

C. Will ingham

$11 / 10 / 94$

TRADEMARK DISCLAIMER. Reference herein to any specific comercial product, process, or service by trade name, trademark, manufacturer, or otherwise, does not necessarily constitute or imply its endorsement, recommendation, or favoring by the United States Government or any agency thereof or its contractors or subcontractors.

This report has been reproduced from the best available copy. Available in paper copy and microfiche. Printed in the United States of America. Available to the U.S. Department of Energy and its contractiors from:

U.S. Department of Energy

office of Scientific and Technical Information (OSTI)

P.0. Box 62

Oak Ridge, TN 37831

Telephone: (615) 576-8401

Available to the public from:

U.S. Department of Commerce

National Technical Information Service (NTIS)

5285 Port Royal Road

Springfield, VA 22161

Telephone: (703) 487-4650 


\begin{tabular}{l|l|c|} 
2. Title & $\begin{array}{l}\text { 3. Number } \\
\text { Waste Receiving and Processing Facility Module 1 } \\
\text { Wata Management System Software Project Management } \\
\text { Plan }\end{array}$ & 4. Rev No. \\
\hline $\begin{array}{l}\text { 5. Key Words } \\
\text { WRAP 1 }\end{array}$ & $\begin{array}{l}\text { 6. Author } \\
\text { DMS }\end{array}$ \\
SWITS & Name: R. E. Clark \\
SPMP & Signature \\
& Organization/Charge Code 62220/R50187 \\
\hline
\end{tabular}

\section{Abstract}

This document provides the software development plan for the Waste Receiving and Processing (WRAP) Module 1 Data Management System (DMS). The DMS is one of the plant computer systems for the new WRAP 1 facility (Project W-026). The DMS will collect, store, and report data required to certify the low level waste (LLW) and transuranic (TRU) waste items processed at WRAP 1 as acceptable for shipment, storage, or disposal.

\section{DISCLAIMER}

This report was prepared as an account of work sponsored by an agency of the United States Government. Neither the United States Government nor any agency thereof, nor any of their employees, makes any warranty, express or implied, or assumes any legal liability or responsibility for the accuracy, completeness, or usefulness of any information, apparatus, product, or process disclosed, or represents that its use would not infringe privately owned rights. Reference herein to any specific commercial product, process, or service by trade name, trademark, manufacturer, or otherwise does not necessarily constitute or imply its endorsement, recommendation, or favoring by the United States Government or any agency thereof. The views and opinions of authors expressed herein do not necessarily state or reflect those of the United States Government or any agency thereof. 


\title{
WASTE RECEIVING AND PROCESSING FACILITY MODULE 1 \\ DATA MANAGEMENT SYSTEM \\ SOFTWARE PROJECT MANAGEMENT PLAN
}

\begin{abstract}
Issued By:
Westinghouse Hanford Company

for the

United States Department of Energy, Richland Operations Office Richland, Washington
\end{abstract}

Prepared by:

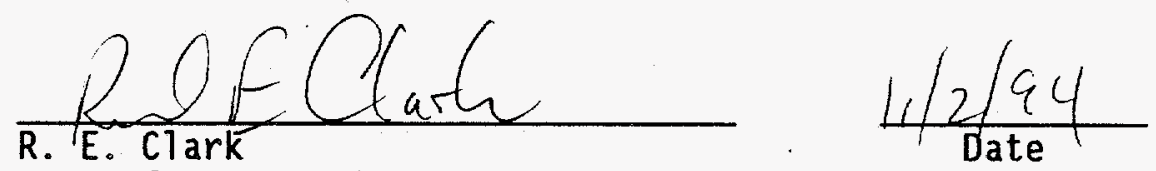

DMS Software Project Manager

Boeing Computer Services Richland, Inc.

Contractor Approval:

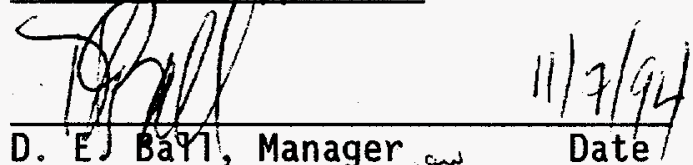

Solid Waste Systems

Engineering

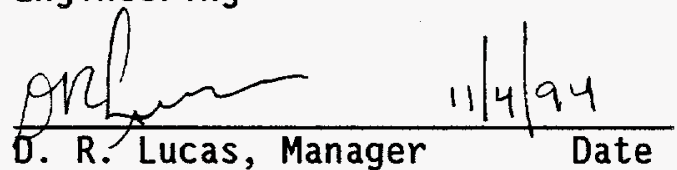

WRAP 1 Project

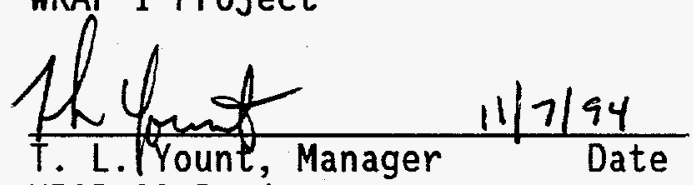

WRAP 2A Project

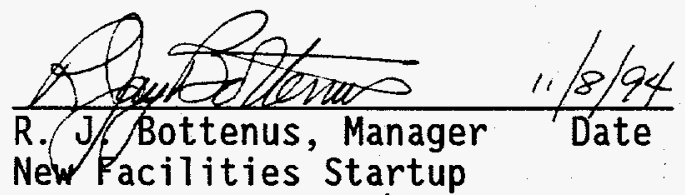

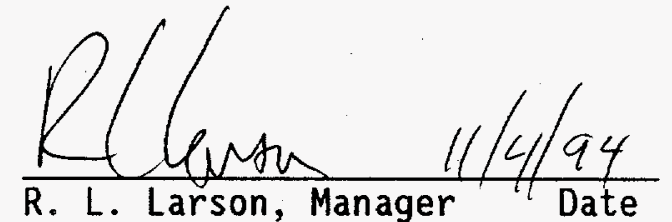
Information Systems Planning and Development

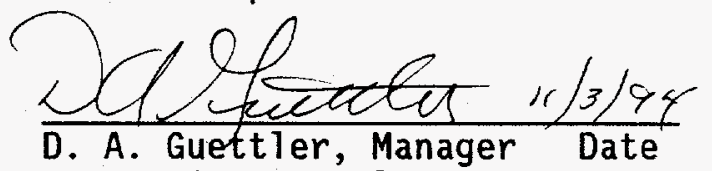

ISS Environmental Systems

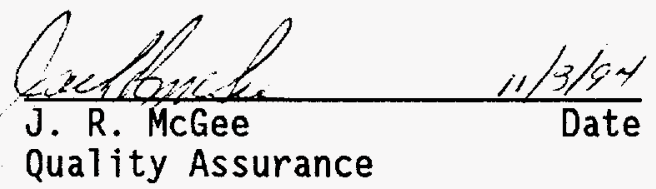


TABLE OF CONTENTS

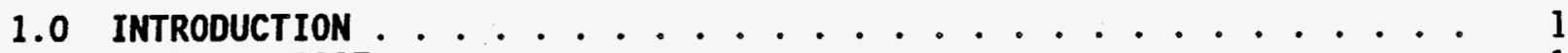

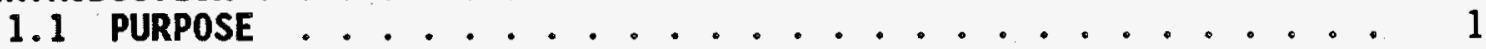

1.2 SCOPE $\ldots \ldots \ldots \ldots$. . . . . . . . . . . . 1

1.3 PROJECT OVERVIEW . . . . . . . . . . . . . 2

1.3.1 Project Purpose/Problem Definition . . . . . . . 2

1.3.2 Project Background History ............. 3

1.3.3 Project Scope ................ . . 3

1.3 .4 Project objectives .............. 3

1.4 PROJECT DELIVERABLES ................. 4

1.4 .1 Software ................. 4

1.4 .2 Documentation .............. 5

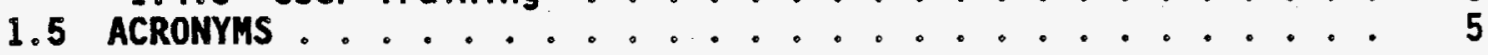

2.0 PROJECT ORGANIZATION . . . . . . . . . . . . . . 6

2.1 PROCESS MODEL . . . . . . . . . . . . . . 6

2.2 ORGANIZATIONAL STRUCTURE ............... . . 7

2.2.1 Customer and User Organizations . . . . . . . 7

2.2.2 Performing organizations ............ 8

2.2.3 Support organizations ............ 9

2.3 ORGANIZATIONAL BOUNDARIES AND INTERFACES ......... 9

2.4 SOFTWARE PROJECT RESPONSIBILITIES . . . . . . . . . 9

3.0 MANAGERIAL PROCESS ............................ 12

3.1 MANAGEMENT OBJECTIVES AND PRIORITIES . . . . . . . . 12

3.2 ASSUMPTIONS, DEPENDENCIES, AND CONSTRAINTS . . . . . . . 12

3.3 ACCEPTANCE CRITERIA . . . . . . . . . . . . . 12

3.4 RISK MANAGEMENT . . . . . . . . . . . . 13

3.5 MONITORING AND CONTROLLING MECHANISMS $\ldots \ldots$

3.5.1 Work Procedures . . . . . . . . . . . . . 13

3.5 .2 Change Authority . . . . . . . . . . 13

3.5.3 Status Reporting . . . . . . . . . . . . 13

3.6 STAFFING PLAN . . . . . . . . . . . . . . 14

4.0 TECHNICAL PROCESS . . . . . . . . . . . . . . 15

4.1 METHODS, TOOLS, AND TECHNIQUES . . . . . . . . . 15

4.2 DOCUMENTATION . . . . . . . . . . . . . . 15

4.3 CONFIGURATION CONTROL . . . . . . . . . . . 15

4.4 ACQUISITION . . . . . . . . . . . . . . . . 15

4.5 DATA MANAGEMENT . . . . . . . . . . . . . . 15

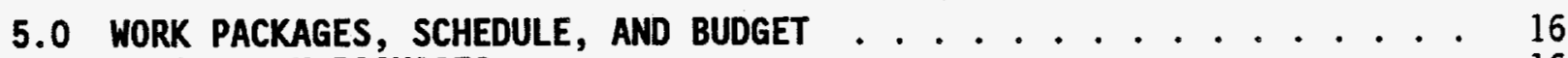

5.1 WORK PACKAGES . . . . . . . . . . . . . . . . . . . 16

5.2 DEPENDENCIES . . . . . . . . . . . . . . 16

5.3 RESOURCE REQUIREMENTS . . . . . . . . . . . 16

5.4 BUDGET AND RESOURCE ALLOCATION . . . . . . . . . . 16

5.5 SCHEDULE ....................... 17

6.0 VERIFICATION AND VALIDATION PLANNING . . . . . . . . . 17

6.1 OVERVIEW . . . . . . . . . . . 17

6.2 DEVELOPMENT CYCLE VERIFICATION AND VALIDATION $\ldots \ldots \ldots \ldots$

6.3 ASSESSMENT . . . . . . . . . . . . . 18 
WHC-SD-W026-SDP-001 REV 0

6.4 INDEPENDENCE . . . . . . . . . . . . . . . . . 19

6.5 VERIFICATION AND VALIDATION REPORTING

6.6 VERIFICATION AND VALIDATION ADMINISTRATION . . . . . . . . . 19

6.7 STANDARDS, PRACTICES, AND CONVENTIONS . . . . . . . . . . . 19

7.0 REFERENCES . . . . . . . . . . . . . . . . 19

APPENDIX A - WORK PACKAGES . . . . . . . . . . . . . . . . . . A-1

APPENDIX B - DMS SOFTWARE PROJECT SCHEDULE . . . . . . . . . . . . . . . B-1

APPENDIX C - STAFFING PLAN AND COST CURVE . . . . . . . . . . . . C-1 


\subsection{INTRODUCTION}

The Waste Receiving and Processing Facility Module 1 (WRAP 1) Data Management System (DMS) Software Project Management PIan (SPMP) is the primary planning document governing the development of the DMS software. This plan is called out in WHC-SD-W026-PAP-002, WRAP 1 Project Activity Plan for Facility Control and Data Management System Development and presents the content specified in WHC-CM-3-10 Software Practices, procedure SP-3.1 Development Management, and by American National Standards Institute (ANSI)/Institute of Electrical and Electronics Engineers (IEEE) Standard 1058.1-1987 Software Project Management Plans.

The SPMP is intended to provide a plan that the customer, end user, and the developer agree to in developing and implementing the computer system as defined in the WRAP Module I DMS Sof tware Requirements Specification (SRS), WHC-SD-W026-CSRS-001: The TRUPACT shipping module, required to support shipment of transuranic (TRU) waste to the Waste Isolation Pilot Plant (WIPP); will be included in the Software Design Description (SDD) to the extent the WIPP data requirements are known. However, the implementation of the TRUPACT module software wi17 be deferred and is not included in this plan.

This plan is a living document that will be reviewed by the software project manager on a periodic basis and revised when necessary to reflect changes in baseline design concepts, schedules, and budgets. At a minimum, the plan will be revised on a yearly basis to reflect the work to be accomplished in the next fiscal year (FY).

\subsection{PURPOSE}

This document describes the management and implementation strategy for development of the WRAP 1 DMS software. It is intended to be used as the software project plan by the customer, end user, and the Boeing Computer Services Richland, Inc. (BCSR) development team to define the DMS scope of work and to provide a detailed plan on how the work is to be accomplished.

\subsection{SCOPE}

This SPMP covers project objectives, strategy, deliverables, organization, management process, technical process, work packages, schedule, budget, and verification and validation (V\&V) activities. The plan controls a11 software activities from the start of the software design phase through operational acceptance testing. The Concept development and Alternatives Analysis were performed by the WRAP 1 Architect Engineer.

- Chapter 2.0 contains the organizational structure, boundaries, responsibilities, and interfaces of this project. The software life cycle model is also described.

- Chapter 3.0 describes the management objectives, priorities, assumptions, dependencies, and constraints of this project; and discusses the risk involved and mechanisms used to monitor and control the scheduled activities. A staffing plan is also presented in this section. 
- Chapter 4.0 addresses the methods, tools, and techniques of the technical development process. It will also describe the software documentation and project support functions.

- Chapter 5.0 describes the work packages, dependencies, resource. requirements, costs, resource allocation, and schedule for the DMS Software Project.

- Chapter 6.0 describes the V\&V process that will be used and the activities to support this process.

- Chapter 7.0 contains project references.

- The Appendices provide the DMS Work Breakdown Structure and task descriptions, the project schedule, and time phased work hour estimates by task.

This document does not constitute an official statement of product requirements. The requirements for the DMS software are specified in the WRAP Module 2 DMS Sof tware Requirements Specification, WHC-SD-W026-CSRS-001.

\subsection{PROJECT OVERVIEW}

\subsubsection{Project Purpose/Problem Definition}

The DMS is one of the plant computer systems for the new WRAP 1 facility, which is being designed and constructed under Westinghouse Hanford Company (WHC) Project W-026. The DMS will be a server based system with terminals located throughout the WRAP 1 facility. The DMS will collect, store, and report data related to WRAP 1 receipt, processing, analysis, packaging, certification, and shipment of Hanford contact-handled retrieved and newly-generated low-level and TRU waste.

Waste characterization and certification data required for WRAP 1 processing will be downloaded from the Solid Waste Information and Tracking System (SWITS) when waste is received. The data will be updated on the DMS to reflect WRAP 1 processing and repacking. Data will be received from the Plant Control System (PCS), the drum non-destructive assay (NDA) Systems Integration Equipment (SIE), the Boxed Waste Assay System (BWAS), and terminals located in the process and office areas. The DMS will generate waste certification and shipping reports for WRAP 1. Waste certification and shipping data will be uploaded to SWITS when the waste is shipped. The data associated with shipped items will be stored on the DMS for one year and then archived to magnetic tape.

The WRAP 1 facility is the first of several new solid waste processing and storage facilities to be constructed as part of the Solid Waste Operations Complex (SWOC). The other SWOC facilities will al so require management of waste characterization and certification data. The WRAP 1 DMS will be designed to be adaptable for use at the other SWOC facilities. The WRAP Module $2 \mathrm{~A}$ facility, for non-thermal treatment of contact handled $10 \mathrm{w}-1$ evel radioactive mixed waste, is currently in Title 2 Design, with Title 2 design scheduled to be completed in December 1995. The software developed for the WRAP 1 DMS will be made available to the WRAP 2A Project. In addition to the basic system design, specific DMS functions which may be useable at WRAP $2 A$ 
include the SWITS communication interface, container location tracking, container relationship tracking, fissile inventory tracking, sample tracking, communication interface with plant control systems, and manual entry and update of waste certification and shipping data.

\subsubsection{Project Background History}

Except for the DMS software, the WRAP 1 control and data systems provided under Project W-026 will be turnkey systems, with the computer hardware and software provided under contract to the ICF Kaiser Hanford Company (ICF KH), WRAP I Construction Manager. The DMS hardware and the PCS hardware and software will be provided by Systems Interface Incorporated (SII), subcontractor to PCL Construction Services, the General Construction Contractor for WRAP 1. Systems Interface Incorporated has selected Hewlett Packard (HP) 9000 computers for both the PCS and the DMS. The drum NDA system and the BWAS are being provided as turnkey systems under separate contracts.

Due to the requirement for data compatibility with SWITS and the similarity between the DMS and SWITS applications, the decision was made that the software for the DMS will be provided by the BCSR organization responsible for the SWITS software. Since the DMS system was specified by the WRAP 1 Project, a BCSR alternatives analys is is not required.

\subsubsection{Project Scope}

The scope of the DMS Software Project is development of al1 DMS software required to support WRAP 1 operation. This includes software design, coding, testing, documentation and initial user training. The scope includes support of interface definitions and integration testing for interfacing with SWITS and the WRAP 1 internal computer systems. Acquisition of hardware and vendorprovided software not provided by the PCS vendor but required for software development will be provided by the WRAP 1 Project and this acquisition is not included in the DMS Software Project scope.

\subsubsection{Project Objectives}

The objective of the DMS Software Project is to provide a data system for WRAP 1 which satisfies regulatory requirements for collecting and reporting waste certification data prior to shipment and permanent disposal of low-level and TRU waste packages. The system must prepare shipping papers and provide SWITS with certification data for items processed at WRAP 1 . The DMS will be a flexible system which can be modified to satisfy the requirements for waste data systems at other SWOC facilities.

\subsubsection{Project Strategy}

The strategy is to use SWITS data base design and software to the extent possible. An HP 9000 development computer and several X-terminals have been acquired by the WRAP 1 Project to support software development. This system will be used by BCSR for DMS software development and testing and by WRAP 1 Project and Operations personnel for PCS screen development and review. 
The DMS production computer will be procured by the vendor providing the PCS and the two computer systems will be installed in the WRAP 1 facility at the same time. Any access to the DMS computer prior to construction turnover to WHC will be subject to approval by ICF KH and the vendor. It is anticipated the vendor will provide WHC/BCSR access to the DMS computer for limited testing while the system is at the factory. Interface simulation software for testing of the DMS interfaces with the PCS, SIE, and BWAS will be provided to the WRAP I Project as part of the DMS software development effort. This software will be used by SII in factory testing and will be used during site acceptance testing of the PCS, SIE, and BWAS.

\subsection{PROJECT DELIVERABLES}

The deliverables that will be produced during the DMS Software Project include the actual computer software, system documentation, and user training. The DMS Software Project will also provide software for factory acceptance testing of computer systems which must communicate with the DMS.

The work will be performed and documentation released under the appropriate sections of WHC-CM-6-1, Standard Engineering Practices (WHC 1988) and WHC-CM-3-10, Software Practices (WHC 1993).

The DMS production computer hardware, the DMS computer UNIX operating system, and the DMS terminals are to be provided by the PCS vendor and are not part of this plan. Any additional hardware and vendor-provided software required for development and operation of the DMS will be procured by the WRAP 1 Project and are not included in this plan. This includes development hardware, Oracle $e^{1}$ database software, language compilers, report generators, personal computer (PC) client software, library utilities, and telecommunications software.

\subsubsection{Software}

\section{- DMS Software}

A11 DMS application software source code developed and tested as part of this project will be provided as a deliverable. The software will meet coding and documentation standards established during software design, including header comments in each software module.

\section{- Simulation Software}

Software source code for the HP 9000 computer will be provided to the WRAP 1 Project to simulate DMS communication with the PCS, SIE, and BWAS. This software will be provided to the computer system vendors for factory testing of their software interfaces to the DMS.

\section{- $\quad$ SWITS Software}

Implementation of the DMS software is dependent upon completion of the SWITS software upgrade.

\footnotetext{
${ }^{1}$ Oracle is a trademark of Oracle Corporation, World Headquarters, 500 Oracle Parkway, Redwood Shores, CA 94063
} 


\subsubsection{Documentation}

Documentation will be developed for the DMS system according to this plan, and all documents will adhere to WHC standards. Each document to be produced will undergo peer reviews as a minimum and all the major documents will be formally reviewed and approved by the WRAP 1 Project, WRAP 1 Startup, and Quality Assurance (QA). They will then be distributed and/or revised in accordance with the WHC-CM-3-10 Software Practices Procedure SP-6.1, Document Control.

Appendix A.

Distribution dates will be as noted within the project schedule in

- Design Phase

SDD

- Implementation Phase

System Test Plan

User Manual

System Test Procedures

- Testing and Installation Phases

Software Configuration Management Plan (SCMP)

Maintenance Plan

\subsubsection{User Training}

User training on the actual operation of the DMS system will occur during the testing and installation phases. Training provided under this plan is limited to training of key users and trainers. The DMS user training required for plant operation will be provided as part of WRAP 1 Operations training program.

\subsection{ACRONYMS}

$\begin{array}{ll}\text { ANSI } & \text { American National Standards Institute } \\ \text { BCSR } & \text { Boeing Computer Services Richland, Inc. } \\ \text { BWAS } & \text { Box Waste Assay System } \\ \text { DMS } & \text { Data Management System } \\ \text { FY } & \text { Fiscal Year } \\ \text { ICF KH } & \text { ICF Kaisers Hanford } \\ \text { IEEE } & \text { Institute of Electrical and Electronics Engineers } \\ \text { HLAN } & \text { Hanford Local Area Network } \\ \text { HP } & \text { Hewlett Packard } \\ \text { NDA } & \text { Non-Destructive Assay } \\ \text { PC } & \text { Personal Computer } \\ \text { PCS } & \text { Plant Control System } \\ \text { QA } & \text { Quality Assurance } \\ \text { RTM } & \text { Requirements Traceability Matrix } \\ \text { SCMP } & \text { Software Configuration Management Plan } \\ \text { SDD } & \text { Software Design Description } \\ \text { SIE } & \text { System Integration Equipment }\end{array}$




$\begin{array}{ll}\text { SII } & \text { Systems Interface Incorporated } \\ \text { SPMP } & \text { Software Project Management Plan } \\ \text { SRS } & \text { Software Requirements Specifications } \\ \text { SWITS } & \text { Solid Waste Information and Tracking System } \\ \text { SWOC } & \text { Solid Waste Operations Complex } \\ \text { TRU } & \text { Transuranic } \\ \text { V\&V } & \text { Verification and Validation } \\ \text { WHC } & \text { Westinghouse Hanford Company } \\ \text { WIPP } & \text { Waste Isolation Pilot Plant } \\ \text { WRAP } & \text { Waste Receiving and Processing }\end{array}$

\subsection{PROJECT ORGANIZATION}

This section of the SPMP describes the project organizational structure, identifies organizational boundaries and interfaces, and defines individual responsibilities for the various project elements.

\subsection{PROCESS MODEL}

The major activities and phases of the development of the DMS computer system will follow a high-level outline which is referred to as a Life Cycle Methodology. The life cycle described here is identical to the preferred life cycle outlined in the WHC-CM-4-2 Quality Assurance Manual and the WHC-CM-3-10 Software Practices Manual, as we11 as the ANSI/IEEE Software Engineering Standards Manual.

The typical life cycle begins when the decision is made to develop a system and ends when the system is no longer in use. Some phases will slightly overlap others, and all rely on each other's successful completion. They are described below:

\section{- Concept Phase}

This phase includes the initial feasibility study and overall system requirements. Usually results in the issuing of a work request.

\section{- $\quad$ Requirements Phase}

Software development is planned and the requirements, including functional and performance capabilities are defined and documented. The primary milestone is the final conclusion of the QA Requirements Review.

\section{- Design Phase}

The design phase expands on the requirements that have been defined, and creates actual working plans for software components, interfacing functions, and system flow processing. A preliminary design may be done, effectively breaking the design into two phases. Primary milestone is the satisfactory completion of the software design review. 
- Implementation Phase

Implementation includes the creation of the software product from design specifications, debugged and prepared for formal testing. Primary milestone is the Test Readiness Review.

- Test Phase

The software product is evaluated to determine whether or not requirements have been satisfied. Testing is closely. monitored and documented. Primary milestone is the successful completion of the V\&V activities review.

- Installation Phase

The software product is integrated into its operational environment and tested in this environment to ensure that it performs as required. May be combined with the Test Phase, so all documented testing takes place under actual conditions which the system will run under.

- Operation and Maintenance Phase

The software product is employed in its operational environment, monitored for satisfactory performance, and modified as necessary to correct problems or to respond to changing requirements.

- $\quad$ Retirement Phase archived.

Support for the product is terminated. System may be replaced or

\subsection{ORGANIZATIONAL STRUCTURE}

The DMS software is being provided for the WRAP 1 Project. The ultimate owner and user of the DMS is the WRAP 1. operations organization. Organization charts for the WRAP 1 Project, WRAP 1 Operations, and the BCSR/ISS organizations responsible for the DMS software are shown in Figure 1. The following sections list the individuals from these organizations who are directly involved with the DMS Software Project management, requirements, and software development.

\subsubsection{Customer and User Organizations}

D. E. Ball, Manager, WRAP Mechanical Engineering, WRAP and Solid Waste Projects - WHC manager in charge of the DMS Software Project.

J. R. Weidert, Engineer, WRAP Mechanical Engineering, WRAP and Solid Waste Projects - WHC Cognizant Engineer for the DMS Software Project.

J. J. Popella, Engineer, WRAP Mechanical Engineering, WRAP and Solid Waste Projects - WHC engineer assisting in the DMS Software Project.

D. L. Lamberd, Engineer, WRAP Mechanical Engineering, WRAP and Solid Waste Projects - WHC Cognizant Engineer for WRAP Module $2 A$ DMS. 
R. J. Bottenus, Manager, New Facility Startup, Restoration and Upgrade Programs - WHC manager in charge of the users of the DMS.

M. E. Palmer, Engineer, New Facility Startup, Restoration and Upgrade Programs - WHC user of the DMS.

B. A. Mayancsik, Engineer, New Facility Startup, Restoration and Upgrade Programs - WHC user of the DMS.

W. A. Robertson, Engineer, New Facility Startup, Restoration and Upgrade: Programs - WHC user of the DMS.

M. L. Sheriff, Engineer, New Facility Startup, Restoration and Upgrade Programs - WHC user of the DMS.

\subsubsection{Performing Organizations}

D. A. Guettler, Manager, Waste Tracking \& Transportation Automated Systems, Information Systems Planning \& Development, Information \& Scientific Systems - BCSR manager in charge of the DMS and SWITS Projects.

R. E. Clark, Software Engineer, Waste Tracking \& Transportation Automated Systems, Information. Systems Planning \& Development, Information \& Scientific Systems - BCSR Project Manager for the DMS and SWITS Projects.

V. H. Bagnall, Systems Analyst, Information \& Scientific Systems - Waste Tracking \& Transportation Systems

A. H. Bivens, Project Administrator, Information \& Scientific Systems Waste Tracking \& Transportation Systems

E. C. Brann II, Software Engineer, Scientific \& Engineering Software Applications, Information \& Scientific Systems - Software Engineer on the DMS Software Project.

R. W. Carey, Software Engineer, Information \& Scientific Systems - Waste Tracking \& Transportation Systems

J. A. Dyck, Software Engineer, Information \& Scientific Systems - Waste Tracking \& Transportation Systems

K. E. Hathaway, Software Engineer, Information \& Scientific Systems Waste Tracking \& Transportation Systems

E. A. Reed, Software Engineer, Information \& Scientific Systems - Waste Tracking \& Transportation Systems

C. K. Rosnick, Software Engineer, Scientific \& Engineering Software Applications, Information \& Scientific Systems - Systems Integration Engineer.

C. A. Seal, Software Engineer, Information \& Scientific Systems - Waste Tracking \& Transportation Systems

P. A. Talmage, Software Engineer, Site Management Information Systems 


\subsubsection{Support Organizations}

- $\quad$ BCSR Telecommunications

Provide requirements, consultation, and review of Hanford Local Area Network (HLAN) interfaces.

- BCSR Network Operations

Provide consultation and support in UNIX system administration and Oracle data base administration.

- Quality Assurance

Review and approve the DMS software documentation. Perform surveillances, inspections, and audits if deemed value added.

- Data Standards and Administration

Review data standards for Data Administration Council.

\subsection{ORGANIZATIONAL BOUNDARIES AND INTERFACES}

Close communication among all departments involved in the DMS system development is necessary to ensure that all individuals are kept well informed of upcoming milestones and are aware of the tasks expected to be completed. Successful peer reviews, walkthroughs, and the eventual product will be a higher quality if everyone is kept knowledgeable of all phases of the project.

The end user interface with the OMS Development Team will be through the DMS customer, WRAP Projects. Clarification of DMS software scope, and technical requirements, and all changes to these requirements will be coordinated through the WRAP Projects.

The WHC Quality Assurance Engineer will have free access to all project personnel for the purpose of quality matters. Corrective action will be initiated by the BCSR Project Manager against any deficiencies which have been noted by the QA Engineer.

\subsection{SOFTWARE PROJECT RESPONSIBILITIES}

\section{- BCSR Software Project Manager}

Responsible for the budgeting, schedule, resource management, and manpower related to the project design and implementation. Responsible for the DMS design, coding, implementation, testing, and overall quality of the system deliverables. Includes actual software coding tasks as well as formulation of al1 deliverable documents. Directs the BCSR staff in work assignments and serves as the primary point of contact between the user organization and BCSR.

- $\quad$ BCSR Systems Integration Engineer 1 systems.

Responsible for all requirements integration of the DMS with other WRAP 


\section{WHC-SD-W026-SDP-001 REV 0}

- $\quad$ BCSR Software Engineer(s)

Responsible for the design, coding, and unit testing of the system software. Tasks also include the formulation of all deliverable documents.

- WHC Cognizant Engineer

A WHC staff member who provides the BCSR project with technical direction. Also responsible for assigning the approval designator for the project.

- WHC Quality Assurance Engineer

A WHC staff member who monitors and advises BCSR on the Quality program. Performs audits and surveillances; and attends system reviews. 


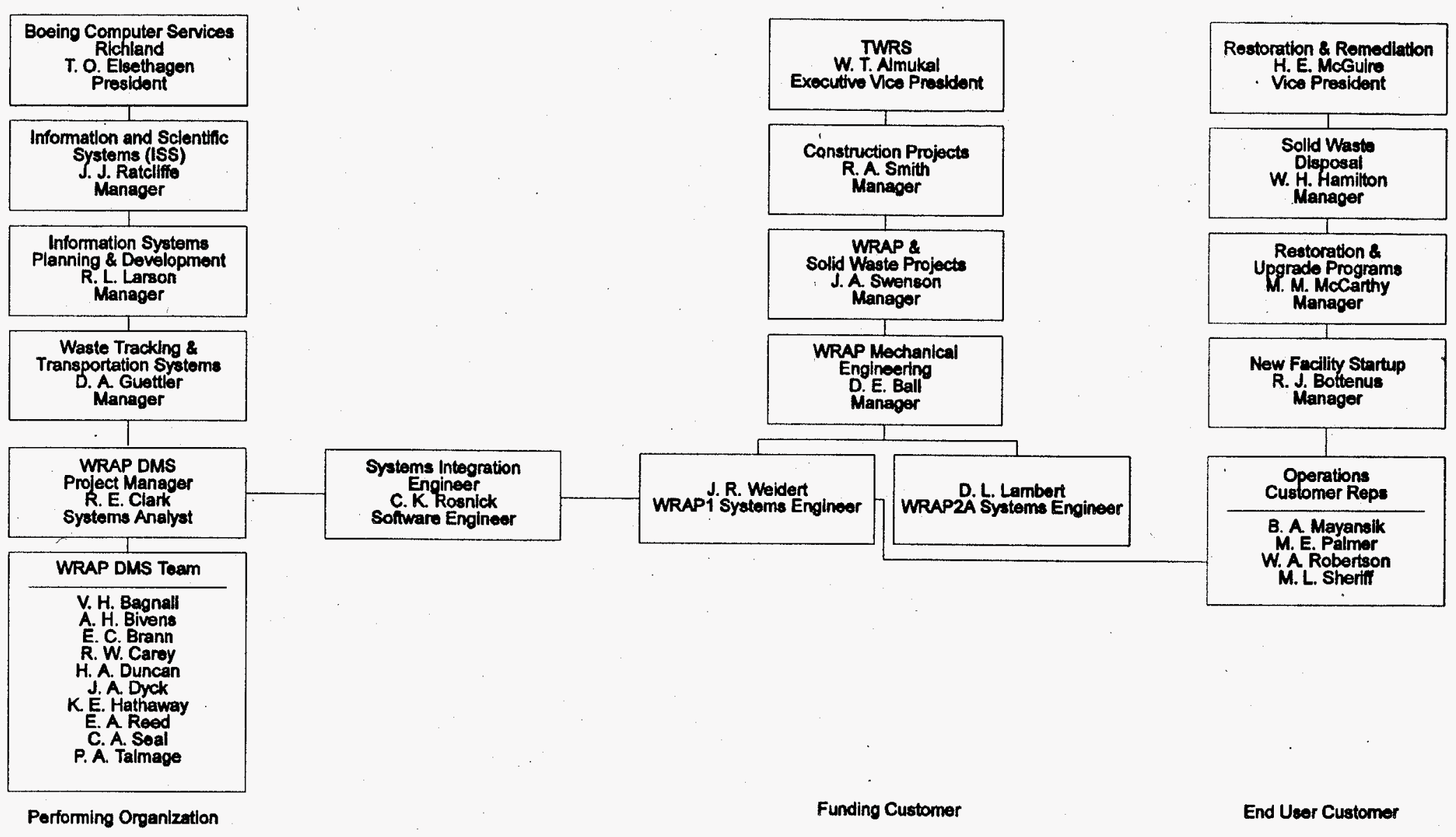

Figure 1 ORGANIZATION CHARTS - DMS CUSTOMER, USER, AND SOFTWARE DEVELOPER 


\subsection{MANAGERIAL PROCESS}

This section of the SPMP specifies management objectives and priorities; project assumptions, dependencies, and constraints; risk management

techniques; monitoring and controling mechanisms to be used; and the staffing plan.

\subsection{MANAGEMENT OBJECTIVES AND PRIORITIES}

The successful implementation of a complete DMS Database and the related software components will require the accomplishment of a series of scheduled tasks. The completion of these tasks as scheduled ensures the timely completion of the overall project.

BCSR shall be committed to keep the customer and end user fully informed of the project status and progress, as follows:

\section{- Design Phase}

The designated customer and end user leads will participate in the scheduled design walkthroughs, in order to become familiar with the design and to ensure their requirements are being satisfied.

Additionally, WRAP 1 Project status meetings for project management are scheduled on a bi-weekly basis. Customer and end user have final signoff on the Detail Design document.

- Implementation Phase

During the actual software code development, status reviews are held on a bi-weekly basis to keep the customer and end user informed of the progress being made.

- Testing/Installation Phase

Customer and end user are involved in the overall system testing. At this stage, all the expected users of the system are given training on the operation, updating capabilities, reporting, etc.

\subsection{ASSUMPTIONS, DEPENDENCIES, AND CONSTRAINTS}

The DMS system will be developed in accordance with the customer and end user requirements as outlined in the SRS, the SDD, and all applicable change requests.

\subsection{ACCEPTANCE CRITERIA}

Customer and end user acceptance of the DMS development will be based on reviews and approvals of all deliverables as defined in section 1.4 of this document, including all documentation and formal acceptance of the completed system.

Detail acceptance criteria will be defined in the Test Plan. The testing process will simulate actual processing conditions using test data as well as actual data. User acceptance of the completed system will be based on the results of this process. 


\section{WHC-SD-W026-SDP-001 REV O}

\subsection{RISK MANAGEMENT}

The development risks listed below have been identified for DMS: The occurrence of any of these risks could have an impact on the timely completion of the project.

- Hardware and/or software not available for development.

- Hardware and/or software training not available.

- Project funding withdrawn.

- Hardware/Software training provided too late in the project, affecting the timely completion of software coding development.

- Changes to the scope of DMS requirements.

- Hardware/Software technical difficulties adversely affecting progress in the development.

\subsection{MONITORING AND CONTROLLING MECHANISMS}

\subsubsection{Work Procedures}

Monitoring and controlling the DMS Software Project development will be accomplished by means of this document, peer reviews by BCSR and Westinghouse personnel, a work breakdown structure, and weekly status reports.

\subsubsection{Change Authority}

Requirement scope changes, design baseline changes, and code baseline changes are documented, evaluated, and approved or disapproved prior to implementation. Detail change record information supports project change in scope positions. Refer to section 4.3.

\subsubsection{Status Reporting}

\subsubsection{Weekly Status Reports}

Weekly status reports will be provided to the customer. The reports will provide as a minimum:

- Accounting of total hours expended during the week (broken down by individual)

- Tasks accomplished by individual

- Interface concerns with other WRAP 1 Contractors

- Significant milestones achieved

- Problems requiring resolution 


\subsubsection{Biweekly Construction Meeting}

A verbal report will be provided at this meeting which will address:

- Interface concerns with other WRAP 1 Contractors

- $\quad$ Significant milestones achieved

- Problems requiring resolution

- DMS Development Schedule Status

- DMS Development Cost Status

\subsubsection{Monthiy Schedule/Project Status}

Presentation to be provided on a monthly basis at the WRAP \& Solid Waste Projects Schedule Integration Meeting.

- DMS Development Schedule Status

- Major milestones met

- DMS Development Cost Status (Update Appendix C Cost Curve)

- Problems requiring resolution

\subsubsection{Ad Hoc Reporting}

To be completed as requested by the DMS Customer.

\subsection{STAFFING PLAN}

The DMS staffing plan by software development phase is presented in the following table. A further breakdown of the staffing plan by month is contained in Appendix $C$.

\begin{tabular}{|l|r|r|r||}
\hline & $\begin{array}{c}\text { Design } \\
\text { Phase }\end{array}$ & $\begin{array}{c}\text { Implementation } \\
\text { Phase }\end{array}$ & $\begin{array}{c}\text { Testing and } \\
\text { Installation } \\
\text { Phase }\end{array}$ \\
\hline \hline Software Project Manager & .5 & .5 & .5 \\
\hline System Integration Engineer & .5 & .5 & .5 \\
\hline System Architect & 1.0 & 1.0 & .5 \\
\hline Software Engineers & 1.8 & 2.7 & .9 \\
\hline Miscellaneous Support & .5 & .5 & .5 \\
\hline
\end{tabular}




\subsection{TECHNICAL PROCESS}

This section of the SPMP specifies the technical methods, tools, and techniques to be used on the project. In addition, the plan for software documentation will be specified, and plans for project support functions such as quality assurance, and configuration management may be specified.

\subsection{METHODS, TOOLS, AND TECHNIQUES}

The DMS Software Project will be developed utilizing structured analysis and design techniques and data modeling. Software development tools for the project will include Oracle Database Management System, Oracle Forms, Oracle Reports, ' $C$ ' language, and operating system. The requirements for any additional software development tools, including use of a graphical user interface, will be determined during software preliminary design.

\subsection{DOCUMENTATION}

The DMS will be documented according to WHC Standard Engineering Practices (WHC-CM-6-1), WHC Quality Assurance (WHC-CM-4-2, Section QR 19.0), and WHC Software Practices (WHC-CM-3-10). All documentation will be released using the WHC Engineering Data Transmittal or Engineering Change Notice system and procedures as outlined in Standard Engineering Practices, WHC-CM-6-1, Section EP-1.7, "Engineering Document Approval and Release Requirements."

\subsection{CONFIGURATION CONTROL}

The DMS SCMP will be prepared and implemented in accordance with WHC-CM-3-10, Software Practices, Procedure SP-3.1, Development Management, and Appendix L, System Configuration Management Plan. The SCMP will be in place prior to final acceptance testing.

The following procedures from WHC-CM-3-10 will be used for configuration control during DMS development:

- SP-6.1, Document Control, for document identification, release, and change control.

- SP-6.2, Software Control, for software control.

- SP-6.3, Change Request and Problem Report, to administer change requests and problem reports.

\subsection{ACQUISITION}

This plan does not include any acquisitions. See Section 1.4.

\subsection{DATA MANAGEMENT}

The DMS Software Project will follow the Data Administration Standards, WHC-CM-2-6, Section 4.0, "Data Administration System Review Process," for compliance. 


\subsection{WORK PACKAGES, SCHEDULE, AND BUDGET}

This section of the SPMP will specify the work packages for the activities and tasks that must be completed, identify the dependency relationships among them, state the resource requirements, provide the allocation of budget and resources to work packages, and establish a project schedule.

\subsection{WORK PACKAGES}

The DMS work breakdown structure in Appendix $A$ has been organized to show the relation to the schedule listed in Appendix $B$ and the cost estimate in Appendix $C$.

\subsection{DEPENDENCIES}

Appendix $B$ describes the ordering of the software development tasks. The major dependencies of the project are the needed hardware, software development tools, training and personnel resources required to complete the project. These dependencies will be satisfied by providing hardware computing resources and the development staff, including ancillary support personnel. required as addressed in this plan.

\subsection{RESOURCE REQUIREMENTS}

The equipment resource requirements for the DMS software development are the availability of a HP 9000 development system with color printer, a PC on HLAN for each developer, and at least one X-terminals with access to the HP 9000 system. The WRAP 1 Project will provide the required hardware, except for the developers PCs which will be provided by BCSR.

Refer to section 4.1 for the software resource requirements.

The resource requirements for personnel on the DMS Software Project are presented in Section 3.6, Staffing Plan.

\subsection{BUDGET AND RESOURCE ALLOCATION}

The total estimated cost for the DMS software development is $\$ 797,500$ in Program dollars, including functional and company overheads. The estimate provides for 69.7 months of BCSR exempt 1abor plus $\$ 10,000$ for travel and training. The actual FY 1994 cost and estimated FY 1995 and FY 1996 costs are presented in the following table. The projected costs are plotted in Appendix $C$ : 


\begin{tabular}{|l||r|r|r|r|}
\hline \multicolumn{7}{|c||}{$\begin{array}{c}\text { DMS SOFTWARE DEVELOPMENT ESTIMATED COST } \\
\text { Program Dollars (thousands) }\end{array}$} \\
\hline PHASE & $\begin{array}{c}\text { FY 1994 } \\
\text { ACTUAL }\end{array}$ & $\begin{array}{c}\text { FY 1995 } \\
\text { ESTIMATE }\end{array}$ & $\begin{array}{c}\text { FY 1996 } \\
\text { ESTIMATE }\end{array}$ & TOTAL \\
\hline \hline Design & 64.8 & 197.5 & & 262.30 \\
\hline Implementation & & 318.5 & & 318.50 \\
\hline Testing & & 77.6 & & 77.60 \\
\hline Installation & & & 119.0 & 119.00 \\
\hline TOTAL & 64.80 & 593.60 & 119.00 & 777.40 \\
\hline
\end{tabular}

The DMS software development budget for FY 1995 is 593.6K Program Dollars under Work Packages 1 A45010701 (WRAP 1) and 1A52010105 (WRAP 2A). During the FY 1995 mid-year review the schedule and cost estimate will be reviewed. At that time the DMS software modules will be reviewed for potential deferral and a decision made whether to time-phase implementation of software modules in addition to the TRUPACT processing module.

\subsection{SCHEDULE}

See Appendix A for the DMS software development schedule. A detailed schedule for implementation of each of the software modules will be provided to WRAP Projects with the draft SDD for review.

\subsection{VERIFICATION AND VALIDATION PLANNING}

\subsection{OVERVIEW}

V\&V is an integral part of the system development activities of the software development life-cycle. The V\&V activities for the DMS are scheduled within this DMS SPMP and a separate V\&V plan will not be prepared.

In order to ensure the accuracy and reliability of the DMS software, each phase of the software life-cycle shall be verified for compliance with previous life-cycle phase requirements and products, satisfaction of the standards, practices and conventions of the phase, and establishment of the next life-cycle phase activities.

This SPMP starts with the design phase of the DMS life cycle. V\&V of the requirements against the WRAP criteria and requirements documents for the DMS is incorporated into the SRS Requirements Traceability Matrix (RTM). There will be a RTM in the SDD and the test plan. 


\subsection{DEVELOPMENT CYCLE VERIFICATION AND VALIDATION}

\subsubsection{Design Phase}

The Design Phase V\&V will document completion of design traceability analysis, design evaluation, design interface analysis, and test design generation. The inputs to the design phase V\&V are the SRS, the SDD and the draft test plan.

\subsubsection{Implementation Phase}

The Implementation Phase V\&V will document source code traceability analysis, source code evaluation, source code interface analysis, source code documentation evaluation, test case generation, test procedure generation, and component test execution. The inputs to the implementation phase V\&V are the SDD, the source code listings, the walk-through results, and the unit testing results.

\subsubsection{Testing Phase}

The Testing Phase V\&V will be preformed following system testing and will include the results from system test execution on the development system. Inputs to the V\&V include the SRS, SDD, the User Manual, test procedures, and test results.

\subsubsection{Installation Phase}

The Installation Phase V\&V will be preformed following system testing and will include the results from acceptance test execution on the production system.

\subsection{ASSESSMENT}

The DMS must provide data and reports to satisfy requirements of the U.S. Department of Energy and a number of regulatory agencies, including the U.S. Department of Transportation, U.S. Environmental Protection Agency, and the Washington State Department of Ecology. The DMS must satisfy the data quality requirements for this reporting. The DMS customer, WRAP Projects, and the DMS user organization, New Facility Startup, will provide the V\&V review to assure these requirements are satisfied.

The DMS is one of a number of WRAP 1 plant computer systems that must work together to provide the plant monitoring, control, waste assay, data acquisition, and reporting required to operate the plant and to certify the waste for shipment and/or disposal. The V\&V activities must assure that the DMS not only provides the required functions, but that the system will properly interface with the other plant computer systems.

The V\&V activities will include review of requirements provided to the WRAP 1 contractors providing the DMS hardware and the other plant computer systems, and review of submittals received from the PCS, SIE, and BWAS contractors. Test software will be provided to the WRAP 1 Project to test the PCS, SIE, and BWAS interfaces with the DMS. 
The DMS must interface with the Hanford SWITS to receive data from SWITS when waste is received at WRAP 1 and to send waste characterization and certification data to SWITS following waste processing. SWITS development team personnel will participate in the DMS design and testing for the V\&V of this interface.

\subsection{INDEPENDENCE}

All V\&V activities will include at least one participant who is not part of the DMS development team. The independent V\&V member must be technically competent. The independent participant may be a software engineer from the SWITS development team.

\subsection{VERIFICATION AND VALIDATION REPORTING} project.

Ongoing V\&V will be performed throughout each phase of the development

\subsection{VERIFICATION AND VALIDATION ADMINISTRATION}

All anomalies identified as a result of V\&V activities will be documented on DMS problem reports. Closure of the anomalies will require concurrence of the software project manager. Any changes to the baseline requirements shall be processed through the normal engineering change control process. The problem report will not be closed until any required changes have been approved.

\subsection{STANDARDS, PRACTICES, AND CONVENTIONS}

The software will meet coding and documentation standards established during software design, including header comments in each software module.

\subsection{REFERENCES}

\section{ANSI/IEEE Software Engineering Standards}

Std 1058.1-1987 Software Project Management Plans

\section{WHC CM-2-6 - Data Administration Standards}

WHC CM-3-10 - Software Practices

SP-3.1 Development Management

SP-3.2 Verification And Validation

SP-3.3 Testing

SP-6.1 Document Control

SP-6.2 Software Control

SP-6.3 Change Request And Problem Report

WHC CM-4-2 - Quality Assurance

QR-19.0 Software Quality Assurance Requirements

WHC CM-6-1 - Standard Engineering Practices

EP-1.6 Data Transmittal

EP-2.1 Software Configuration Management

EP-2.2 Eng. Document Change 
EP-5.8 Eng. Document Content Guidelines

WHC-SD-W026-CSRS-001, WRAP Modu7e 1 Data Management System Software

Requirements Specification, Rev 0, September 14, 1994, Westinghouse Hanford Company.

WHC-SD-W026-PAP-002, WRAP 1 Project Activity Plan for Facility Control and Data Management System Development, Rev 0, February 1, 1994, Westinghouse Hanford Company. 
WHC-SD-W026-SDP-001 REV O

\section{APPENDIX A - WORK PACKAGES}

A-1 
WHC-SD-W026-SDP-001 REV 0

\section{DMS WORK PACKAGES}

\subsection{DESIGN}

\subsection{Preliminary Design}

The overall process flow is charted showing the flow and interfaces between components. Each computer and/or peripheral operation is then decomposed into enough detail to show the data flow. The Data Dictionary is formulated, and processing modules are defined. The SWITS SDD is reviewed to identify specific reports, screens, data elements and data tables. The approved PCS/DMS communication protocol from SII is required prior. to completion of this activity.

\subsection{Detail Design}

The screen formats, system menus, report formats and data base structure are designed. The different input, output routines and formats with their entities, attributes, and control requirements are described. The miscellaneous system functions that are essential to the internal operation are designed.

\subsection{Design Walkthroughs}

The design will undergo a peer review on a module-by-module basis by the use of walkthroughs conducted as the work progresses. A sign-off of each module will be part of the project record.

\subsection{Prepare Draft Software Design Description (SDD)}

A draft SDD is prepared for peer review before distribution to the customer, end user, $Q A$, and Data Administration. Peer review comments are incorporated prior to formal document review.

\subsection{SDD Review for Comment}

The customer, end user, $Q A$, and other project participants will have a two week period in which to comment on the SDD. All comments will be resolved and changes incorporated.

\subsection{SDD Review for Approval}

The SDD is reviewed for approval.

\subsection{SDD Issued}

The approved SDD document is issued.

\subsection{Data Administration Council Review}

The approved SDD is provided to the Data Administration Council to satisfy WHC-CM-2-6, Section 4.0, design review requirements. The WHC Data Directory is updated. 
WHC-SD-W026-SDP-001 REV 0

\subsection{Data Administration Board Review}

Data Administration Board review may be required.

\subsection{Developer Training}

The BCSR development staff is trained on appropriate software packages referenced in 4.1 .

\subsection{Establish Database Development Platform}

Establish the DMS development platform by setting up an Oracle database with a subset of the SWITS data structure and functions on the WRAP 1

development computer. The development HP 9000 computer must be in place and the Oracle software installed before this task can start.

\subsection{Prototype and Interface Development}

Prototype software is developed to evaluate software design alternatives. The prototype software developed as part of this activity includes man-machine interfaces and communication software interfaces to the other computer systems, including the PCS, SIE, BWAS and SWITS. The prototype development will be done on the HP 9000 development system and the SWITS development machine, utilizing the development platform established under 1.3. The DMS development hardware and software must be in place before this development can start.

\subsection{IMPLEMENTATION}

\subsection{System Test P1an}

The Test Plan is completed which includes test scripts and methodology descriptions for unit and acceptance testing.

\subsection{Initial PCS Interface Simulation Software}

Develop HP 9000 software to simulate communication with the PCS for initial interface testing by the PCS vendor.

\subsection{Final PCS Interface Simulation Software}

Complete development of HP 9000 software to simulate communication with the PCS. This software is to be provided to the WRAP 1 project for use in acceptance testing.

\subsection{BWAS Interface Simulation Software}

Develop HP 9000 software to simulate communication with the Boxed Waste Assay System (BWAS). This software is to be provided to the WRAP 1 project for use in acceptance testing. 


\subsection{SIE Interface Simulation Software}

Develop HP 9000 software to simulate communication with the Drum NDA System Integration Equipment (SIE) computer. This software is to be provided to the WRAP 1 project for use in acceptance testing.

\subsection{DMS Software Construction}

Code all tables, screens, reports, interfaces, etc. per the specifications outlined in the Detail Design. Software construction may include but is not limited to the following:

- Database Initiation

- Code SWITS interface processes

- Code PCS interface processes

- Code NDA/NDE interface processes (SIE, BWAS)

- Code Commands, system routines, tables, etc.

- Code menu/entry processes

- Code inquiry/display processes

- Code update processes

- Code reports

- Code Fissile Loading Calculation Programs

\subsection{Module Walkthroughs}

Each module is described in detail to the programming staff program-byprogram in relation to the detail design and checked for technical correctness.

\subsection{Module Unit Testing}

Each constructed program is tested by the software engineer for accuracy to the approved design.

\subsection{User Manual}

The User Manual is developed which provides the user with detailed system operation instructions.

\subsection{System Test Procedures}

Test procedures are prepared for testing to be performed during the testing phase.

\subsection{TESTING}

\subsection{System Testing}

The system is tested on the development system according to approved test procedures. The types of testing done in this activity include component testing, system testing, and acceptance testing. The interfaces to the PCS, BWAS, and SIE will be simulated for this testing. 
WHC-SD-W026-SDP-001 REV 0

3.2 Test Report

A Test Report is issued detailing the results of the testing.

3.3 SRS and SDD Revision (As-built)

The SRS and SDD are revised to reflect the final design as tested.

3.4 Software Configuration Management Plan

\subsection{INSTALLATION AND ACCEPTANCE}

\subsection{Operating Procedures}

All required operating procedures are completed and the User Manual is updated, if needed.

\subsection{Maintenance Plan}

The plan for maintenance of the system is completed.

\subsection{User Training}

Training is conducted according to the approved Training Plan.

\section{$4.4^{\circ}$ Software Installation and Checkout}

The DMS software is installed on the DMS production ( $p 1$ ant) computer. The system is checked out to ensure the software performs as tested in the development environment, prior to the start of formal acceptance testing. Any errors discovered are corrected. Version controls are in place. DMS software installation on the plant DMS computer will be done following Construction Manager release of the system to the WRAP 1 Project.

\subsection{WRAP 1 Acceptance Testing Support}

Operational and technical support is provided during the formal WRAP 1 DMS acceptance testing.

\subsection{Update/Complete Documentation}

The DMS documentation is updated, as required, to incorporate any changes made during the installation and testing.

\subsection{DMS System Acceptance}

Final approval of the system by the customer and end user reflecting satisfactory accomplishment of documented acceptance criteria. 


\subsection{PROJECT MANAGEMENT}

\subsection{Status Reporting and Reviews}

\subsubsection{Weekly Status Reporting}

A written status report is submitted weekly to by the BCSR Project Manager to the WRAP 1 Cognizant Engineer, New Facility Startup Cognizant Engineer, BCSR developers, and cognizant management.

\subsubsection{Customer and End User Status Reviews}

Customer and end user will meet with BCSR staff bi-weekly to review the progress during the design phase. This activity will be augmented by a monthly report.

\subsubsection{Monthly Customer and End User Reviews}

A monthly review of project status and resource consumption is conducted with WRAP 1 and ISS management participation.

\subsubsection{ISS Functional Reviews}

Monthly functional review of DMS progress is conducted.

\subsection{Monitor and Control Project Resources}

The BCSR Project Manager monitors and controls resource allocation and resource usage against forecasts.

\subsection{Budget Planning}

Budget forecasts and activity recommendations are made for budget planning.

\subsection{Change Request Processing}

The BCSR Project Manager administers and coordinates approved DMS change requests.

\subsection{SPMP Review and Update}

The Software Project Management Plan will be reviewed annually and updated as required. 


\section{WHC-SD-W026-SDP-001 REV 0}

The following tasks are not part of the DMS Software Development Project but are required to implement the DMS interface to the SWITS system. The work is to be funded by the SWITS customer.

- $\quad$ SWITS/DMS Interface SRS

The requirements for modification to the SWITS software to support WRAP 1 reporting and to interface to the WRAP 1 DMS are identified. The SWITS SRS is revised and approved.

- SWITS SDD Revision

The design changes required to implement the new requirements are identified. The SWITS SOD is revised and approved to reflect these changes.

- SWITS Software Revision

The SWITS software is modified to incorporate the changes authorized in the SDD revision.

- SWITS Users Manual Revision

The SWITS Users Manual is revised.

- $\quad$ SWITS Upgrade Testing

The SWITS software is tested, including the transfer of data between SWITS and the DMS. 
WHC-SD-W026-SDP-001 REV 0

APPENDIX B - DMS SOFTWARE PROJECT SCHEDULE 
DATA MANAGEMENT SYSTEM IDMSI SOFTWARE DEVELOPMENT

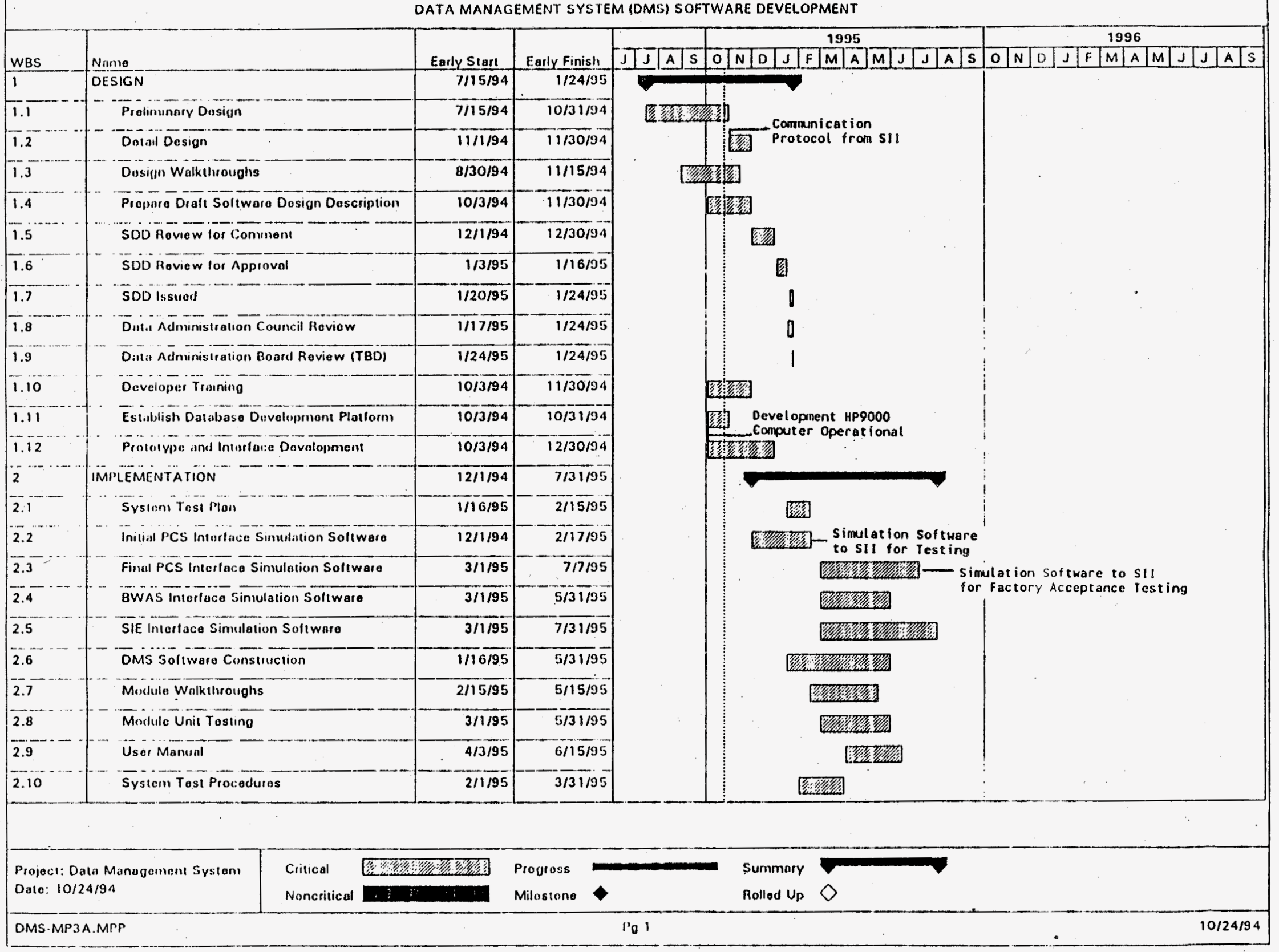




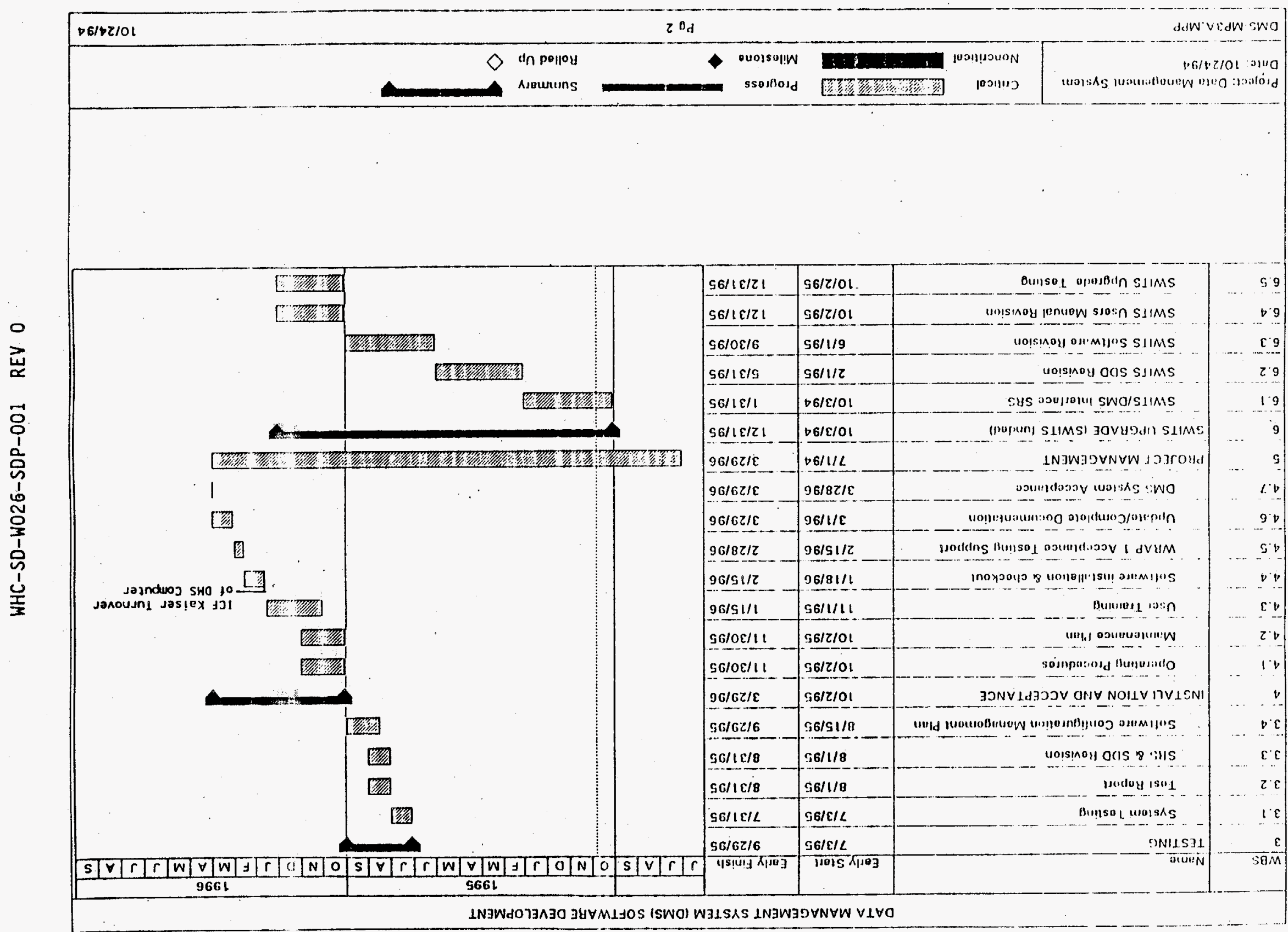


WHC-SD-W026-SDP-001 REV 0

APPENDIX C - STAFFING PLAN AND COST CURVE 


\begin{tabular}{|c|c|c|c|c|c|c|c|c|c|c|c|c|c|c|}
\hline \multicolumn{15}{|c|}{ FY 1995 DATA MANAGEMENT SYSTEM } \\
\hline POSITION & NAME & Oct & Nov & Dec & Jan & Feb & Mar & Apr & May & Jun & JuT & Aug & Sep & Total \\
\hline Software Project Manager & Clark & .5 & .5 & .5 & .5 & .5 & .5 & .5 & .5 & .5 & .5 & .5 & .5 & 6.00 \\
\hline System Integration Engineer & Rosnick & .5 & .5 & .5 & .5 & .5 & .5 & .5 & .5 & .5 & .5 & .5 & .5 & 6.00 \\
\hline System Architect & $\begin{array}{l}\text { Dyck } \\
\text { Talmage } \\
\end{array}$ & 1.0 & 1.0 & 1.0 & 1.0 & 1.0 & 1.0 & 1.0 & 1.0 & 1.0 & .5 & .5 & .5 & 10.50 \\
\hline Analyst/Programmer & Brann & 1.0 & 1.0 & 1.0 & 1.0 & 1.0 & 1.0 & 1.0 & .5 & .5 & .5 & .5 & .5 & 9.50 \\
\hline Oracle Programmer & Reed & .4 & .4 & .4 & 1.0 & 1.0 & 1.0 & 1.0 & 1.0 & 1.0 & .5 & .5 & .5 & 8.70 \\
\hline c Programmer & Carey & .4 & .4 & .5 & .7 & .7 & .7 & .7 & .5 & .5 & .4 & .4 & .4 & 6.30 \\
\hline HP 9000 System Admin. & $\begin{array}{l}\text { Black } \\
\text { Grambihler }\end{array}$ & .25 & .25 & .25 & .25 & .25 & .25 & .25 & .25 & .25 & & & & 2.25 \\
\hline Oracle Database Admin. & $\begin{array}{l}\text { Parker } \\
\text { Gilberg }\end{array}$ & .25 & .25 & .25 & .25 & .25 & .25 & .25 & .25 & .25 & & & & 2.25 \\
\hline TOTAL & & 4.30 & 4.30 & 4.40 & 5.20 & 5.20 & 5.20 & 5.20 & 4.50 & 4.50 & 2.90 & 2.90 & 2.90 & 51.50 \\
\hline
\end{tabular}

\begin{tabular}{|c|c|c|c|c|c|c|c|c|c|c|c|c|c|c|}
\hline \multicolumn{15}{|c|}{ FY 1996 DATA MANAGEMENT SYSTEM } \\
\hline POSITION & NAME & Oct & Nov & Dec & Jan & Feb & Mar & Apr & May & Jun & Jul & Aug & Sep & Total \\
\hline Software Project Manager & clark & .3 & .3 & .3 & .3 & .3 & .3 & & & & & & & 1.80 \\
\hline System Integration Engineer & Rosnick & .2 & .2 & .2 & .2 & .2 & .2 & & & & & & & 1.20 \\
\hline System Architect & $\begin{array}{l}\text { Dyck } \\
\text { Talmage }\end{array}$ & .3 & .3 & .3 & .3 & .3 & .3 & & & & & & & 1.80 \\
\hline Analyst/Programmer & Brann & .3 & .3 & .3 & .3 & .3 & .3 & & & & & & & 1.80 \\
\hline Oracle Programmer & Reed & .3 & .3 & .3 & .3 & .3 & .3 & & & & & & & 1.80 \\
\hline $\begin{array}{l}\text { Application/System } \\
\text { Programmer }\end{array}$ & Carey & .3 & .3 & .3 & .3 & .3 & .3 & & & & & & & 1.80 \\
\hline TOTAL & & 1.70 & 1.70 & 1.70 & 1.70 & 1.70 & 1.70 & 0.00 & 0.00 & 0.00 & 0.00 & 0.00 & 0.00 & 10.20 \\
\hline
\end{tabular}




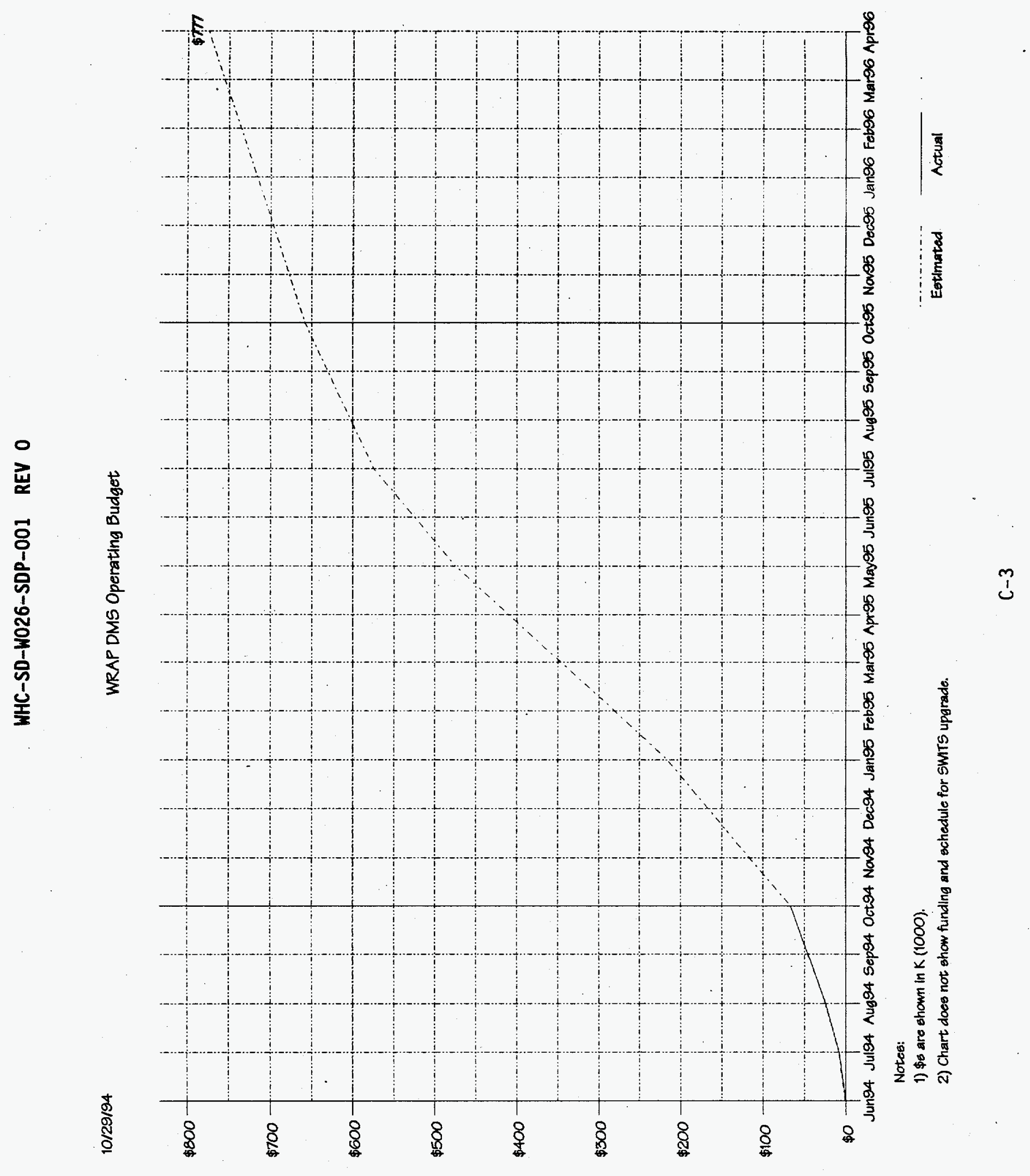

